\title{
Establishment of human sperm-specific voltage-dependent anion channel 3 recombinant vector for the production of a male contraceptive vaccine
}

\author{
Asmarinah, ${ }^{1}$ Endang W. Bachtiar, ${ }^{2}$ Amarila Malik, ${ }^{3}$ Susan Rahayu ${ }^{1}$ \\ ${ }^{1}$ Department of Biology, Faculty of Medicine, Universitas Indonesia, Jakarta, Indonesia \\ ${ }^{2}$ Department of Oral Biology, Faculty of Dentistry, Universitas Indonesia, Jakarta, Indonesia \\ ${ }^{3}$ Department of Pharmacy, Faculty of Mathematic and Natural Sciences, Universitas Indonesia, Jakarta, Indonesia
}

\begin{abstract}
Abstrak
Latar belakang: Tujuan penelitian ini adalah untuk membuat konstruksi vektor rekombinan gen Voltage-Dependent Anion Channel isoform 3 (VDAC3) spesifik sperma manusia, untuk produksi antibody VDAC3 yang berpotensi sebagai bahan kontrasepsi laki-laki.
\end{abstract}

\begin{abstract}
Metode: Fragmen target untuk pembuatan vektor rekombinan adalah gen VDAC3 spesifik sperma manusia, yang diperoleh dengan cara mengamplifikasi cDNA dari sperma manusia melalui metode PCR menggunakan primer spesifik gen VDAC3 exon 5 sampai dengan exon 8 . Vektor rekombinan gen VDAC3 dikonstruksi dengan cara mengklon produk PCR tersebut (435 pb) ke vektor ekspresi pET101/D-TOPO (5753 pb). Selanjutnya bakteri E. coli TOP10 ditransformasi dengan vektor rekombinan di atas. Hasil klon gen VDAC3 pada vektor dikonfirmasi dengan pemotongan vektor rekombinan dengan enzim restriksi XbaI dan metode PCR colony pada bakteri yang tumbuh dengan menggunakan primer VDAC3 exon 5-8.
\end{abstract}

Hasil: Analisis BLAST dari amplifikasi gen VDAC3 sperma manusia dengan primer spesifik exon 5 sampai exon 8 menunjukkan 94\% identik dengan data gene bank. Bakteri E. coli transforman yang berhasil tumbuh ada 12 klon. Hasil elektroforesis vektor rekombinan VDAC3 yang telah dipotong dengan enzim restriksi XbaI, dari 12 klon yang tumbuh menunjukkan pita berukuran 6181 pb pada 8 klon bakteri. Setelah dilakukan metode PCR colony diperoleh pita berukuran 435 pb selanjutnya setelah disekuensing diperoleh sekuen amplicon yang 94\% identik dengan gen VDAC3 manusia.

Kesimpulan: Penelitian ini berhasil membuat konstruksi vektor rekombinan gen VDAC3 spesifik untuk sperma manusia, untuk pengembangan bahan kontrasepsi laki-laki di masa datang. (Med J Indones. 2012;21:61-5)

\begin{abstract}
Background: The aim of this study was to construct a recombinant vector of human sperm specific VDAC3 gene for production of VDAC3 antibody, which is potential as male contraception vaccine.

Methods: Target fragment sequence of VDAC3 gene was obtained through amplification of human sperm VDAC3 cDNA with primers covering exon 5 to exon 8. Its PCR product in size of $435 \mathrm{bp}$ was cloned to the pET101/D-TOPO expression vector $(5753 \mathrm{bp})$. E. coli bacteria were transformed with this vector. Cloning of VDAC3 fragment gene to the vector was confirmed by the using of XbaI restriction enzyme and PCR colony method with primers covering exons 5-8 of the human VDAC3 gene.

Results: Alignment analysis of amplified fragment covering exon 5 to exon 8 of VDAC3 gene showed 94\% homology to human VDAC3 gene from databank. After cloning to the expression vector and transformation to $E$. coli competent cells, twelve colonies could grow in culture media. Gel electrophoresis of sliced VDAC3 recombinant vector showed a single band in the size of $6181 \mathrm{bp}$ in 8 colonies. After application of PCR colony and amplicon sequencing, the result showed a single band in the size of $435 \mathrm{bp}$ and fragment sequence with 94\% identity to human VDAC3 gene.

Conclusion: The construction of human sperm specific VDAC3 gene recombinant vector was established in this study. In the future, this recombinant vector will be used to produce VDAC3 antibody for the development of a male contraception vaccine. (Med J Indones. 2012;21:61-5)
\end{abstract}

Keywords: Contraception, recombinant vector, sperm, VDAC3

The fast population growth in many countries, such as Indonesia, has been a major problem; therefore, the family planning program needs to be implemented widely and effectively. Until recently, male contraception was always associated with the problems of low efficiency, irreversibility and unwanted side effects. Development of tools or materials for male contraception is still underway, one of them is the immune-contraception method., ${ }^{1,2}$ One of the target proteins that can affect sperm function is the specific ion channel protein on the sperm. ${ }^{3}$ Voltage dependent anion channels (VDACs) are mainly found in the outer membrane of mitochondria. ${ }^{4}$ These channels also known as porins are responsible for the flux of ions and metabolites including ATP from and to mitochondria in the cell. ${ }^{5-7}$ There are three different VDAC genes encoding distinct isoforms in mammals, i.e. VDAC1, VDAC2 and VDAC3. Each of these proteins is highly conserved in human, rat and mouse. VDAC proteins are found also in cattle and in the tail of human sperm. ${ }^{8-10}$ A "VDAC3-deficient mouse" study revealed low sperm motility of homozygote mutant mice. ${ }^{11}$ Our 
study showed various mutations in exons 5, 6, 7 and 8 of VDAC3 gene which occurred in low motile sperm from asthenozoospermic patients. ${ }^{12,13}$ In our previous studies with a porin 2 (VDAC2) polyclonal antibody decrease of bovine sperm motility was statistically not significant, whereas a VDAC3 polyclonal antibody decreased human sperm motility significantly. ${ }^{14,15}$ Providing monoclonal antibodies against spermspecific proteins in order to diminish sperm function is prospective in the development of male contraceptive strategies. ${ }^{1}$ The aim of this study was to design human sperm-specific VDAC3 cDNA and to construct a recombinant vector of its gene.

\section{METHODS}

\section{Primer design}

We refer to gene bank Acc No. NM_005662 (http://www. ncbi.nlm.nih.gov/pubmed/) with target sequences of exons 5, 6, 7 and 8 of the VDAC 3 gene. The primer design for this study is based on previous studies in an attempt to cover the expression of VDAC3 gene starting from exon 5 through exon 8, i.e. 5 ' TTGGCTGAAGGGTTGAAACT 3' and 5' GAGAAGTTCTACAATCCAGC 3'. These primer pairs were used to amplify VDAC 3 cDNA from human sperm cells, which yielded an amplicon size of $428 \mathrm{bp}$ as target sequence for the construction of a recombinant vector.

\section{Human sperm collection}

Human normozoospermic sperm was isolated by Percoll-density gradient centrifugation ( $45 \%$ and $90 \%$ ) using Percoll solution (Pharmacia, Uppsala Sweden) in Cramer medium. Spermatozoa were collected from the bottom layer (density of $90 \%$ ). The sperm pellet was washed and stored in $-20^{\circ} \mathrm{C}$.

\section{Sperm RNA isolation and cDNA VDAC3 production}

Total sperm mRNA was extracted by using TRIzol reagent (Invitrogen, Carlsbad USA) and DNA contamination was digested by DNase. Synthesis of cDNA (reverse transcription) was catalyzed by Superscript III RT (Invitrogen, Carlsbad USA). Amplification of VDAC3 cDNA target sequence used PCR technique (Kapa Biosystem, Boston, USA). The PCR system was performed for 35 cycles at $94^{\circ} \mathrm{C}$ for 2 minutes, $94^{\circ} \mathrm{C}$ for 30 seconds, $60.2^{\circ} \mathrm{C}$ for 30 seconds, $72^{\circ} \mathrm{C}$ for 30 seconds and $72^{\circ} \mathrm{C}$ for 5 minutes. To obtain a blunt end PCR product for cloning to the expression vector of pET 101/D-TOPO with the size of $5753 \mathrm{bp}$ (Figure 1), the forward primer was added by CACC ATG overhang sequence. The integrity and yield of the

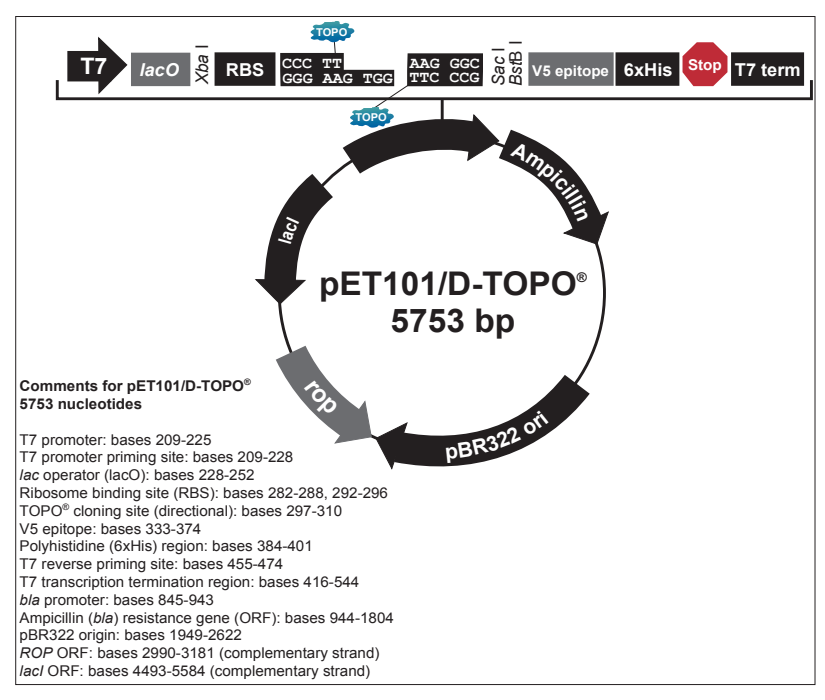

Figure 1. Map and feature of pET 101/D-TOPO vector (Invitrogen, Carlsbad USA) ${ }^{16}$

product was confirmed by agarose gel electrophoresis using a 100 bp DNA ladder as marker.

\section{Construction of a VDAC3 gene recombinant vector}

Insertion of VDAC3 gene target to pET 101/D-TOPO vector using the TOPO directional cloning system and subsequent transformation to $E$. coli TOP 10 competent cells using TOPO directional cloning as well as transformation reactions were performed according to the Invitrogen protocol (Invitrogen, Carlsbad USA). Positive transformed E. coli was selected on Luria Bertani (LB) medium, and was subsequently analyzed by isolating the recombinant plasmid with the alkaline lyses method by GeneJet Plasmid Purification Kit (Fermentas, Vilnius Lithuania). The insertion of the VDAC3 target sequence was confirmed by restriction enzyme using $\mathrm{XbaI}$ as well as by PCR colony method.

\section{RESULTS}

The inserted VDAC3 fragment gene in the size of $435 \mathrm{bp}$ - as total length of exons $5-8(428 \mathrm{bp})$ and CACCATG overhang - can be observed on agarose gel electrophoresis of the reverse transcription-PCR product (Figure 2). BLAST analysis showed that the target sequence is a $94 \%$ match to human VDAC3 gene (Figure 3).

VDAC3 target sequence was successfully inserted into the pET101/D-TOPO expression vector and transformed to $E$. coli TOP10 cells. The positive result was shown by the growth of transformed cells in culture medium. There were 12 colonies of positive transformant (data not shown). 


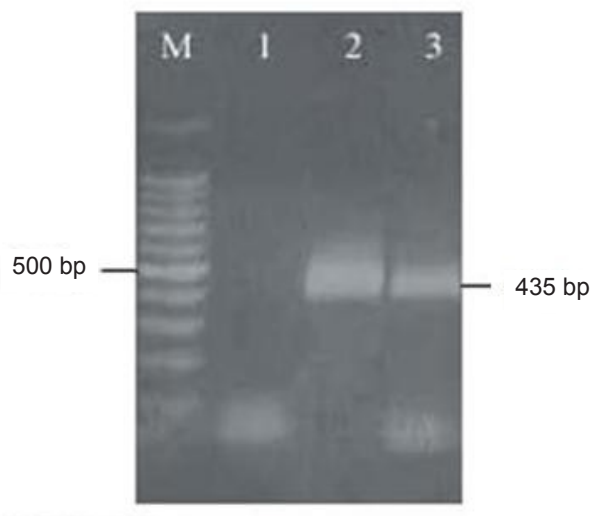

M : DNA Marker

1 : Negative control

2 : PCR product with primer FIRI from Hela cDNA

3 : PCR product with primer FIRI from human sperm cDNA

Figure 2. Agarose gel electrophoresis of amplified human sperm VDAC3 cDNA. The amplicon in size of 435 bp is the target fragment for cloning to pET 101/DTOPO vector

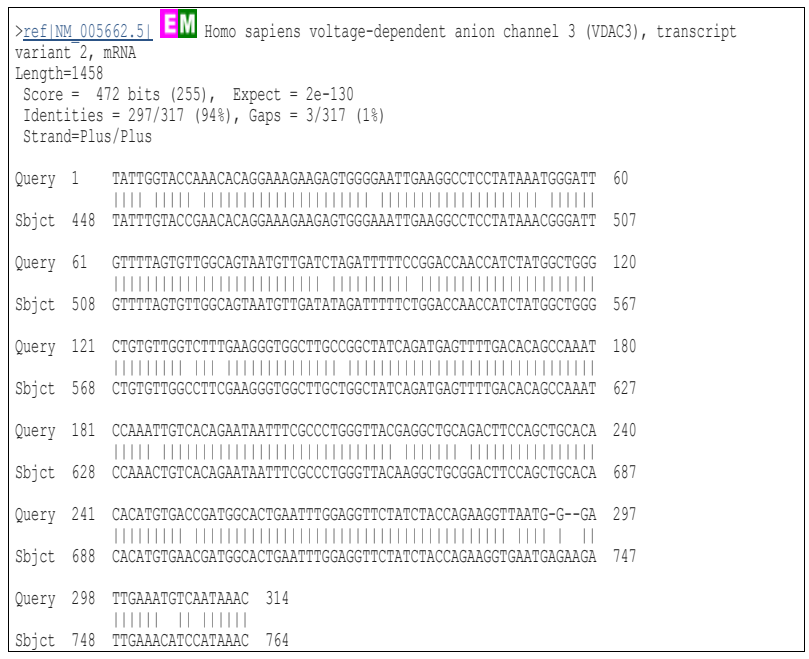

Figure 3. Sequencing results of amplicon or VDAC3 target gene showed a 94\% match to VDAC3 mRNA sequence (NM_005662.5)

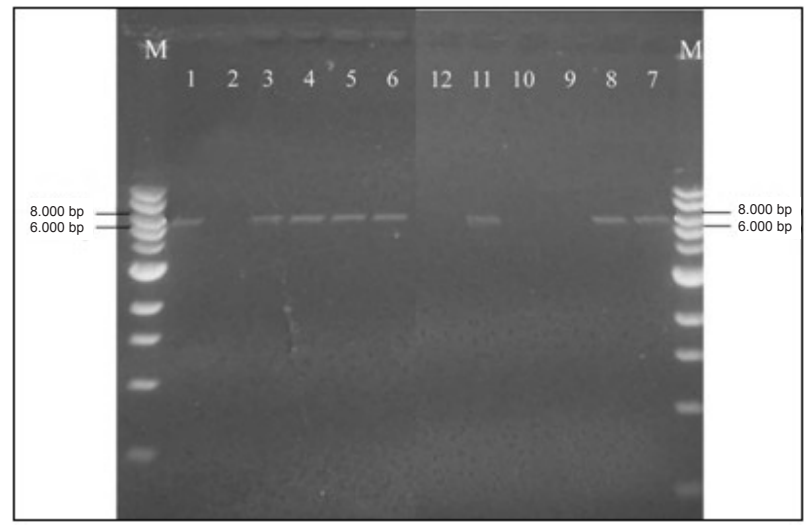

Figure 4. Agarose gel electrophoresis of XbaI-cut VDAC3 recombinant vector, which results in a single band of $6181 \mathrm{bp}$ in the colony numbers $1,3,4,5,6,7,8$ and 11

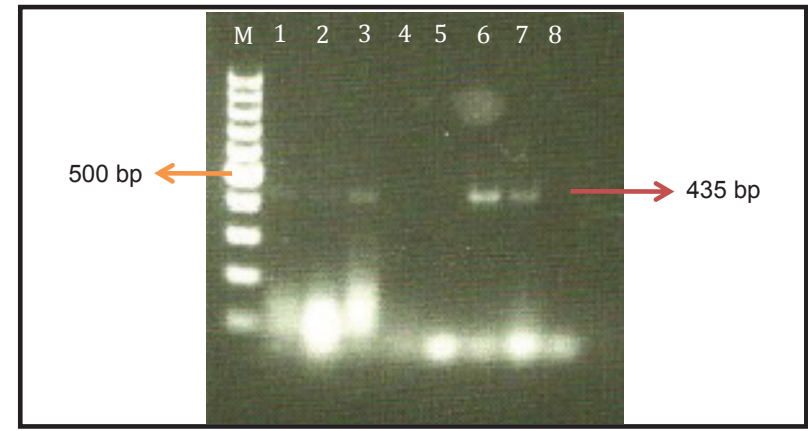

Figure 5. Gel electrophoresis of the PCR colony product from 8 colonies of E. coli TOP10. $M=$ marker; lanes 1,2,3,6,7 show positive inserts in the size of $435 \mathrm{bp}$; lanes 4,5,8 have no insert

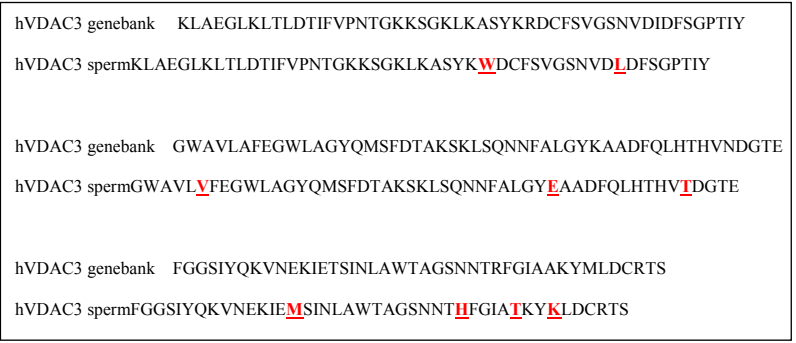

Figure 6. Comparison of hVDAC3 fragment gene from genebank and sperm. Nine amino acids were different between both sequences (indicated by underline)

The insertion of VDAC3 target sequence with overhang nucleotide in the size of $435 \mathrm{bp}$ was confirmed by cutting the recombinant plasmids from 12 colonies with XbaI restriction enzyme. Eight out of 12 colonies verified positive bands in the size of $6181 \mathrm{bp}$, i.e. colony numbers $1,3,4,5,6,7,8$ and 11 (Figure 4). The insertion of VDAC3 fragment gene was confirmed by the PCR colony method as single band of $435 \mathrm{bp}$ in gel electrophoresis (Figure 5). Sequencing of the PCR colony product was also $94 \%$ match to human VDAC3 sequence.

\section{DISCUSSION}

In this study, we successfully established a recombinant vector for human sperm VDAC3 gene. The inserted VDAC3 gene was a 94\% match to human VDAC3 gene in the databank leading to change 9 amino acids of the VDAC3 polypeptide sequence. The sequence comparison between published hVDAC3 fragment gene and sperm-obtained VDAC3 fragment gene is shown in figure 6.

The presence of nucleotide changes in the inserted fragment suggests the possibility as a fragment gene of sperm-specific VDAC3 sequence. A new VDAC3 isoform with a single amino acid insertion was reported. It appears to arise by tissue-specific 
alternative splicing of a 3-base exon. ${ }^{17} \mathrm{VDAC} 3$ has $65-70 \%$ amino acid similarity to the other two VDAC isoforms. Unlike VDAC1 and VDAC2, VDAC3 is able to only partially complement a temperaturesensitive YVDAC-deficient yeast strain when grown on glycerol-based media, suggesting that this isoform may have distinct physiological functions. ${ }^{17,18}$ The functions of the VDAC3 isoform were demonstrated by a study with mice lacking VDAC3, which showed that male mice were infertile. Although they had normal sperm numbers, spermatozoa exhibited markedly reduced motility. Structural defects were found in two-thirds of epididymal axonemes. ${ }^{11}$

Three VDAC isoforms are expressed in a wide variety of tissues and cells of mammals including humans. Among the cells in the testis, VDAC1 is mainly located in Sertoli cells, VDAC2 in late spermatocytes and spermatids, and VDAC3 in all cell types of testis, especially in Leydig cells. ${ }^{9,19,20}$ It has been reported that high amounts of VDAC2 and VDAC 3 protein was found in bovine sperm flagella, especially in a subcellular component named outer dense fibres (ODF). AntiVDAC antibodies against VDAC isoforms functionally lead to a loss of the acrosomal cap, surface alterations of the sperm head, coiled sperm tails and sperm cell volume disturbances. ${ }^{9,21}$ In our preliminary study antiVDAC2 antibody decreased bovine sperm motility, but these results were statistically not significant. ${ }^{14}$ Our subsequent evaluation of anti-VDAC3 antibody demonstrated a significant decrease of human spermatozoa motility. ${ }^{15}$

Insertion of the sperm-specific VDAC3 gene to our recombinant vector could be proved by XbaI enzyme cutting in eight colonies of bacteria culture, while only five out of eight colonies showed presence of inserted gene by means of PCR colony method. It may be caused by failure of gene amplification in three colonies.

Based on studies in mammals and humans, we suppose that VDAC protein, especially the VDAC3 isoform perform important functions in sperm normal structure and motility. Generating an antibody towards the VDAC3 isoform that can interfere with these functions might be the first step to develop a male contraception vaccine. Development of a human immunocontraceptive vaccine based on a sperm-specific antigen is a rational concept, because it has long been known that sperm are highly immunogenic in both females and males. Many sperm protein antigens have been investigated as the basis for fertility-regulating vaccines. ${ }^{1,2}$ Our spermspecific VDAC3 recombinant vector will further be used to produce purified VDAC3 protein for generating antibodies. In the future, these antibodies might be applied as a passive vaccine that could decrease human sperm motility.

In conclusion, this study has established the construction of a VDAC3 gene recombinant vector generated specifically from human sperm transcript. This vector will be used to produce recombinant VDAC3 protein. This protein will be applied and investigated to generate the antibody for a male contraception vaccine.

\section{Acknowledgment}

This study was funded by competence-based cluster research grant 2010 from Universitas Indonesia.

\section{REFERENCES}

1. McLaughlin EA, Aitken RJ. Is there a role for immunocontraception? Mol Cell Endocr. 2011;335(1):78-88.

2. Anderson RA, Baird DT. Male contraception. Endocr Rev. 2002;23(6):735-62.

3. Cooper TG, Yeung CH. Physiology of sperm maturation and fertilization. In: Nieschlag E, Behre HM, editors. Andrology. 2nd ed. Berlin: Springer; 2000. p. 63-82.

4. Bathori G, Parolini I, Szabo I, Tambola F, Messina A, Oliva $\mathrm{M}$, et al. Extramitochondrial porin: facts and hypotheses. J Bioenerg Biomembr. 2000;32(1):79-89.

5. Rostovtseva T, Colombini M. ATP flux is controlled by a voltage-gated channel from the mitochondrial outer membrane. J Biol Chem. 1996;271(45):28006-8.

6. Rostovtseva T, Colombini M. VDAC channels mediate and gate the flow of ATP: implications for the regulation of mitochondrial function. Biophys J. 1997;72(5):1954-62.

7. Okada SF, O'Neal WK, Huang P, Nicholas RA, Ostrowski LE, Craigen WJ. Voltage-dependent anion channel-1 (VDAC-1) contributes to ATP release and cell volume regulation in murine cells. J Gen Physiol. 2004;5:513-26.

8. Gincel D, Zaid H, Shoshan-Barmatz V. Calcium binding and translocation by voltage-dependent anion channel: a possible regulatory mechanism in mitochondrial function. Biochem J. 2001;358:147-55.

9. Hinsch KD, de Pinto V, Aires VA, Schneider X, Messina A, Hinsch E. Voltage-dependent anion-selective channels VDAC2 and VDAC3 are abundant protein in bovine outer dense fiber, a cytoskeletal component of the sperm flagellum. J Biol Chem. 2004;279(15):15281-8.

10. Liu B, Wang Z, Zhang W, Wang X. Expression and localization of voltage- dependent anion channels (VDAC) in human spermatozoa. Biochem Biophys Res Comm. 2009;378:366-70.

11. Sampson MJ, Decker WK, Beaudet AL, Ruitenbeek $\mathrm{W}$, Armstrong D, Hicks MJ, et al. Immotile sperm and infertility in mice lacking mitochondrial voltagedependent anion channel type 3. J Biol Chem. 2001;276(42):39206-12.

12. Asmarinah, Nuraini T, Atmadja DS, Moeloek NH. Mutation in exon 6 of VDAC3 (porin isotype 3) gene in sperm with low motility. Procedding on 8th International Congres of Andrology, Seoul, South Korea (free paper). 2005:31-35.

13. Asmarinah, Nuraini T, Sumarsih T, Paramita R, Saleh MI, Narita V, et al. Mutations in the exons 5, 7 and 8 of human VDAC3 gene in the sperm with low motility. Andrologia. 2011;44:46-52. 
14. Asmarinah, Hinsch KD, Aires VA, Hinsch E. Effect of antiporin type 2 antibodies upon bovine sperm motility and acrosomal status. Andrologia. 2003;35:2(A).

15. Asmarinah, Saleh MI, Wanandi SI, Narita V, Damayanti $\mathrm{R}$, Moeloek N, et al. Polyclonal VDAC3 antibody decreases human sperm motility: a novel approach to male contraception. Med J Indones. 2011;20(1):5-10.

16. Invitrogen ${ }^{\mathrm{TM}}$. Champion ${ }^{\mathrm{TM}} \mathrm{pET}$ directional $\mathrm{TOPO}^{\circledR}$ expression kits. Five-minute, directional $\mathrm{TOPO}^{\circledR}$ cloning of blunt-end PCR products into vectors for high-level, inducible expression in E. Coli. Catalog nos. K100-01, K101-01, K102-01, K151-01. K200-01. Version H. 2006 Oct 30. Available from: http://tools.invitrogen.com/content/ sfs/manuals/pettopo man.pdf

17. Sampson MJ, Lovell RS, Craigen WJ. The murine voltagedependent anion channel gene family. Conserved structure and function. J Biol Chem. 1997;272(30):18966-73.

18. Sampson MJ, Ross L, Decker WK, Craigen MJ. A new isoform of the mitochondrial outer membrane protein VDAC3 via alternative splicing of 3-base exon. J Biol Chem.1998;273(46):30482-6.

19. Hinsch KD, Asmarinah, Hinsch E, Konrad L. VDAC2 (porin-2) expression pattern and localization in the bovine testis. Biochim Biophys Acta. 2001;1518(3):329-33.

20. Liu B, Wang Z, Zhang W, Wang X. Expression and localization of voltage-dependent anion channels (VDAC) in human spermatozoa. Biochem Biophys Res Commun. 2009;378(3):366-70.

21. Triphan X, Menzel VA, Petrunkina AM, Cassara MC, Wemheuer W, Hinsch KD, et al. Localisation and function of voltage-dependent anion channels (VDAC) in bovine spermatozoa. Pflugers Arch. 2008;455:677-86. 